\title{
Seed Yield and Quality of Sword Bean (Canavalia gladiata (Jacq.) DC.) Produced in Poland
}

\author{
Xianzong XIA ${ }^{1 *}$, Ruoxi YIN ${ }^{1}$, Wei HE ${ }^{1}$, Barbara GÓRNA², \\ Roman HOŁUBOWICZ ${ }^{1}$
}

\author{
${ }^{1}$ Poznań University of Life Sciences, Department of Plant Pathology, Seed Science and Technology, Seed Science and Technology Division, \\ Baranowo, ul. Szamotulska 28, 62-081, Przeźmierowo, Poznań, \\ Poland; xianzongx@foxmail.com (*orrespondingauthor),576444534@qq.com;100099574@qq.com; rbseed@up.poznan.pl \\ ${ }^{2}$ Department of Fermentation and Biosynthesis, Institute of Food Technology of Plant Origin, Faculty of Food Science and Nutrition, Poznan \\ University of Life Sciences, ul.Wojska Polskiego 31,60-624 Poznań, Poland; baslag@up.poznan.pl
}

\begin{abstract}
Sword bean (Canavalia gladiata (Jacq.) DC.) also called Jack bean or beach bean, originates from India and China. The crop has been completely unknown in Poland and other Central European countries. Two Chinese cultivars: early and late ones, were produced in Western Poland. During the vegetation period, additional watering, staking and chemical control against aphids and bean weevils were applied. In the field, plant emergence rates, blooming period, number of seeds per pod and total seed yield were evaluated. In the laboratory, 1000 seed weight, seed germination, vigour and water absorbing capacity were evaluated. Both cultivars had good emergence rates in the field - over 60\%. Only the early cultivar produced germinating seeds when grown in Poland, whereas the late one produced soft and immature seeds of the size of the wheat grain. On average, one pod had 7.3 seeds. The early cultivar gave good seed yield $-2,067.00 \mathrm{~kg} \mathrm{ha}^{-1}$. The germination capacity of the produced seeds was over $90 \%$. The mean germination time was shorter at $25^{\circ} \mathrm{C}$ than at $15{ }^{\circ} \mathrm{C}$. Water absorption capacity curves, although different for the 1 hour time point, were basically the same for both Chinese and Polish seeds. The total proteins content for both cultivars was almost 25\%. In the climatic conditions of Western Poland in the field, it was possible to produce high amounts of seeds with high germination capacity of the early sword bean cultivar.
\end{abstract}

Keywords: Jack bean, seed size, seed germination, seed vigour, water absorption capacity, chemical contents

\section{Introduction}

Sword bean (Canavalia gladiata (Jacq.) DC.), sometimes also called Jack bean or beach bean, originates from India and China (Black et al., 2006; Zhang and Yang 2007; Ma et al., 2009; Yang and Ma 2010; Luo et al., 2015) and has spread throughout the tropics (Moteetee, 2016). The crop has high commercial value and has been widely produced in the Far East countries (Liu, 1994; Du et al., 2009). It is primarily produced in China in the area of the Yangtze River basin and southern provinces: Anhui, Hubei, Guangdong, Guangxi, Jiangxi, Shanxi, Sichuan, Jiangsu and Taiwan ( $\mathrm{Li}$ et al., 2007). The crop is considered to be an underutilized legume (Ekanayake et al., 2000) and so far, it has been completely unknown in Poland and other Central European countries.

Sword bean is a warm-season annual crop ( $\mathrm{Li}$ et al., 2007; Huang, 2008). It has high light and temperature requirements, considerable adaptability to all types of soils and showed better tolerance to drought than other legumes, but at the same time, it showed no tolerance to waterlogging (Ma et al., 2009). Long-time low temperature during blooming leads to light colour of leaves or even yellow leaves and it had a negative effect on its growth (Yang et al., 2014). The lack of light, in turn, leads to a crop's reduction in the number of flowers and pods. In northern China, due to insufficient heat and shorter vegetation period, transplanting of seedlings to the field after they had emerged in the greenhouse, is recommended (Ma et al., 2009).

Sword bean seeds are also used in traditional Chinese medicine (Chen et al., 2001). They have high proteins and low fats contents. Medicines produced from the vegetable can stop vomiting, limit coughing, lower soring and injury pain, cure hernia and dysentery, heal up lumbago due to renal deficiency and stop pains around kidneys and waist (Zhu and Wang, 2002; Duranti, 2006; Li et al., 2007; Ma et al., 2009). 
562

The main purpose of this experiment was to obtain germinating seeds of sword bean in the climatic conditions of Western Poland, evaluate their quality and check contents of selected chemical compounds in them.

\section{Materials and Methods}

Materials

Two Chinese cultivars: early (white seeds) and late (pink seeds), were produced in the field in Western Poland. The seeds of early cultivar (Chinese name: 'Jingpin Jiadouwang') were bought in a seed shop for professional gardeners in Harbin (Heilongiiang Province) in northern China in 2014. The seeds of the late cultivar (Chinese name: 'Hong Daodou') were bought in the Zheng Yang Horticultural Seed Company in Shenzhen (Guangdong province) in southern China in 2015. The cultivars were all from the institutes of vegetable breeding in the Heilongiiang (Manchuria) and Guangdong Provinces, respectively.

\section{Weather conditions}

In terms of weather conditions, during two years of the carried out field experiment, 2015 was better than 2016, because the first one was cool and wet, whereas the latter hot but dry (Table 1). The average air day temperatures in 2015 fluctuated from $13.3^{\circ} \mathrm{C}$ to $22.5^{\circ} \mathrm{C}$ and were typical as in the years 2005 - 2013, except August, in which it was 3.6 ${ }^{\circ} \mathrm{C}$ higher than before. For 2016, the air temperatures fluctuated from $17.0^{\circ} \mathrm{C}$ to $23.0^{\circ} \mathrm{C}$ and were not typical as in previous years, i.e. they were higher in all months than in the other years. In terms of monthly sums of precipitation, both years were not typical. For 2015, in June and July, they were almost the same or higher than in the previous years and in September - lower than before. For 2016, these values were much lower than in the years 2005 - 2013 except August. In conclusion, the years 2015 and 2016 were considered as very good and good for sword bean production, respectively (Table 1 ).

\section{Fields and soil}

The experiments on the early and late cultivars were carried out in 2015 and 2016, respectively, at the Marcelin Experiment Station of the Faculty of Horticulture and
Landscape Architecture, at PULS. The fields used for the experiments were not used for any other crops in the previous year. Just before sowing the seeds, the rotation machine was used to destroy weeds. The used soil was podsol.

\section{Soil analysis}

Before starting the field experiment, in March, 2015 and 2016, routine chemical analyses were conducted to confirm contents of macro- and microelements, proper acidity $(\mathrm{pH})$ and salinity (EC) in the soil. The results were provided by the Department of Plant Nutrition, at the Faculty of Horticulture and Landscape Architecture, at PULS. The received results of the soil analyses were: high contents of $\mathrm{P}$, $\mathrm{Ca}, \mathrm{Cu}$, low amount of $\mathrm{N}\left(\mathrm{N}-\mathrm{NH}_{4}, \mathrm{~N}-\mathrm{NO}_{3}\right), \mathrm{S}-\mathrm{SO}_{4}$, proper $\mathrm{pH}$, low salinity (Table 2), so no additional fertilizing during the vegetation was used. The results of the soil analysis of 2016 were almost the same - it was slightly more $\mathrm{N}-\mathrm{NO}_{3}$ so they were not shown.

\section{Starting the experiment}

The early cultivar seeds were dressed with chemical fungicide Zaprawa Nesienna T 75 DS/WS. It was a fungicide used commonly to control fungal diseases on the seeds and in the soil especially seedling's rot (caused by fungi of the genera: Fusarium, Colletotrichum and Phoma) and it was used as a powder or water liquid and worked by contacting seeds. The seeds were sown in the field on April $21^{\text {st }}$ and $22^{\text {nd }}, 2015$ in 4 rows of 200 seeds each. The row spacing was $10 \mathrm{~cm}$ and $1 \mathrm{~m}$ between two rows. At first, a furrow $4 \mathrm{~cm}$ deep in the soil was prepared within one row. Then, the soil was used to cover the seeds and pressed with a rake. For the late cultivar seeds, 6 rows of 200 seeds each were sown on April 29 ${ }^{\text {th }}, 2016$.

Bamboo sticks were set before plants reached $1 \mathrm{~m}$ in height. In order to eliminate aphids and bean weevils (Acanthoscelides obtectus), $0.15 \%$ Pirimor $500 \mathrm{WG}$ and $0.1 \%$ Falcon $460 \mathrm{EC}$ were used twice for spraying plants.

\section{Field observation}

In the field, plant emergence rates, blooming period, main development stages and number of seeds per pod were recorded.

Table 1. Mean air day temperatures $\left({ }^{\circ} \mathrm{C}\right)$ and monthly sums of precipitation $(\mathrm{mm})$ at the Marcelin Experiment Station of the Poznań University of Life Sciences (PULS) in individual years 2015 and 2016 as well as in the years 2005-2013

\begin{tabular}{|c|c|c|c|c|c|c|}
\hline \multirow{2}{*}{ Month } & \multicolumn{3}{|c|}{ Mean air day temperature $\left({ }^{\circ} \mathrm{C}\right)$} & \multicolumn{3}{|c|}{ Sum of precipitation $(\mathrm{mm})$} \\
\hline & $2005-2013$ & 2015 & 2016 & $2005-2013$ & 2015 & 2016 \\
\hline May & 14.8 & 13.3 & 20.0 & 52.0 & 27.2 & 35.0 \\
\hline June & 17.1 & 15.9 & 21.0 & 95.1 & 93.6 & 37.0 \\
\hline July & 19.8 & 19.4 & 23.0 & 75.8 & 86.6 & 52.0 \\
\hline August & 18.9 & 22.5 & 21.0 & 37.7 & 23.6 & 42.0 \\
\hline September & 13.8 & 14.7 & 17.0 & 46.5 & 21.8 & 37.0 \\
\hline
\end{tabular}

The data on weather conditions in 2015 and the years 2005-2013 during the field experiment was provided from the Marcelin Experiment Station of PULS. The data for 2016 was taken from the Internet: https://www.worldweatheronline.com/

Table 2. Soil analysis from the field of the experiment for 2015

\begin{tabular}{|c|c|c|c|c|c|c|c|c|c|c|c|c|c|c|c|}
\hline \multirow{2}{*}{ Sample } & \multicolumn{7}{|c|}{ Macro-elements (mg/100g d.w. soil) } & \multicolumn{6}{|c|}{ Micro-elements (mg/kg d.w. soil) } & \multirow{2}{*}{$\begin{array}{c}\mathrm{pH} \\
\left(\mathrm{H}_{2} \mathrm{O}\right)\end{array}$} & \multirow{2}{*}{$\begin{array}{c}\text { Salinity } \\
(\mathrm{mS} / \mathrm{cm})\end{array}$} \\
\hline & $\mathrm{N}-\mathrm{NH}_{4}$ & $\mathrm{~N}-\mathrm{NO}_{3}$ & $\mathrm{P}$ & $\mathrm{K}$ & $\mathrm{Ca}$ & $\mathrm{Mg}$ & $\mathrm{S}-\mathrm{SO}_{4}$ & $\mathrm{Fe}$ & $\mathrm{Zn}$ & $\mathrm{Mn}$ & $\mathrm{Cu}$ & $\mathrm{B}$ & $\mathrm{Cl}$ & & \\
\hline Soil in the field & 0.4 & tr.. $^{*}$ & 8.7 & 7.9 & 42.1 & 3.9 & 0.2 & 98.1 & 17.2 & 34.4 & 4.3 & 0.65 & 10.5 & 6.47 & 0.08 \\
\hline $\begin{array}{l}\text { Standard for } \\
\text { common bean }\end{array}$ & $\mathrm{N}-\mathrm{NH}_{4}+$ & $\mathrm{NO}_{3}: 2.5-$ & $3.0-6.0$ & $5.0-8.0$ & $25.0-40.0$ & $3.0-6.0$ & $1.0-3.0$ & $75.0-120.0$ & $5.0-25.0$ & $20.0-50.0$ & $1.0-4.0$ & $0.5-1.5$ & $10.0-50.0$ & $5.5-6.5$ & $<0.35$ \\
\hline
\end{tabular}




\section{Seed yield and quality}

Total seeds yield, 1000 seeds weight, seed germination and vigour and water absorption capacity were evaluated.

Additionally, selected morphological characteristics of sword bean seeds produced in the field in Poland were measured. These were: seed length, width and thickness. They were calculated by vernier caliper.

After the seeds produced in Poland were dry, vigour tests on blotter were conducted at the Division of Seed Science and Technology in Baranowo. The germination tests in the sand were performed in the W. Legutko Plant Breeding and Seed Production Company. Germination, vigour tests and 1000 seeds weight of the collected seeds were carried out following the routine method described in the International Seed Testing Association (ISTA) rules (Anonymous, 2012).

Water absorption capacity test; 40 seeds harvested in Poland and 40 seeds from China were divided into 8 groups of 10 seeds each. They were then put into a beaker of distilled water. The weight of seeds in each group was recorded every hour.

\section{Dry matter and total proteins contents evaluation}

When the plants were ready for harvest, 400 seeds were taken and sent to the chemical laboratory of the Department of the Fermentation and Biosynthesis, the Institute of the Food Technology of the Plant Origin, at PULS. The analyses included dry matter and total proteins contents evaluation.

The dry matter evaluation was conducted following the method worked out by Drzazga (Drzazga, 1999).

Total proteins content was determined following the method developed by Kryłowska-Kułas (Kryłowska-Kułas, 1993).

\section{Statistical analysis}

The data received in the experiment was subjected to statistical analysis, including the analysis of variance MANOVA. The significant differences were calculated based on Duncan's test for $\alpha=0.05$. The means with significant differences were marked with different letters for morphological seed characters. For some data, standard deviation values were also calculated.

\section{Results}

\section{Field emergence rates}

For both cultivars, the seeds germinated and emerged in the field evenly over $60 \%$.

\section{Main development stages}

The sword bean plants produced in Poland showed 5 main development stages (Table 3 ). The seeds were sown at the end of April. The second stage was before the plants reached $1 \mathrm{~m}$ in height and, at this stage, they were staked. The third important development stage was blooming. In the Polish climatic conditions, for early cultivar, it started at the end of June and lasted until the end of vegetation. For the late one, it started at the beginning of August and it was prolonged until the first week of September. Throughout plant growth, new flowers were set and then they also bloomed. Two colours flowers of the late cultivar were found during the experiment: white and pink ones. The next two stages were pod ripeness to be eaten fresh and seed maturation. For the late cultivar, only few pods were set and no ripen seeds were produced.

\section{Seed yield and quality}

Only the early cultivar produced germinating seeds when grown in Poland. For the late one, on October 5th, 2016, when the field experiment was finished, the set pods were still soft, with unformed and immature seeds. Their size was not bigger than that of wheat grain. Although the seeds were not matured, they had to be harvested because they had stopped growing due to chilling temperatures and night frosts.

\section{Seed size}

Comparison of standard deviation values of each replication for 3 analyzed seed characters showed that the greatest variability was recorded for seed length, whereas the smallest - for seed width (Table 4, Figs. 1 - 3).

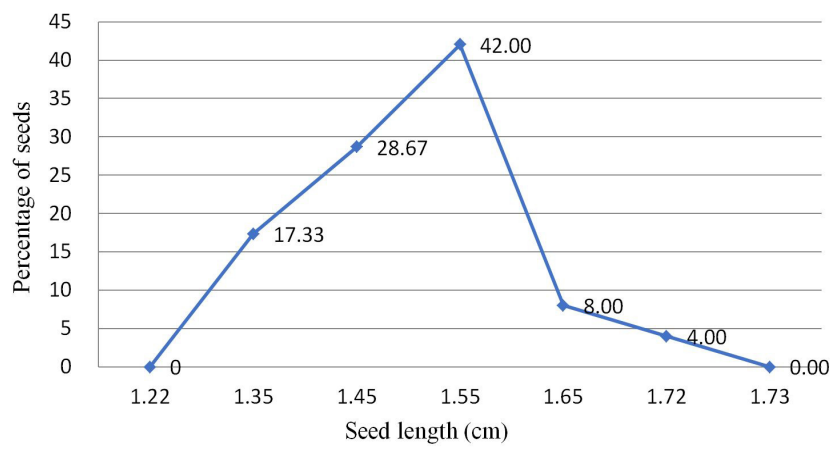

Fig. 1. A curve characterizing variability in length of sword bean seeds

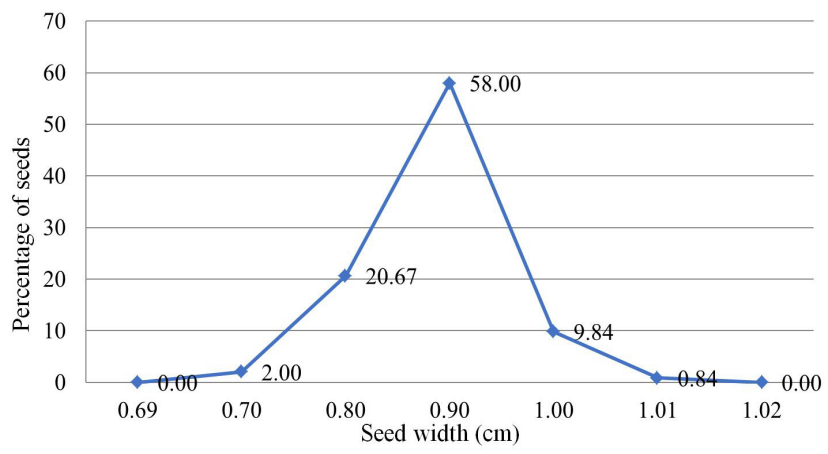

Fig. 2. A curve characterizing variability in width of sword bean seeds

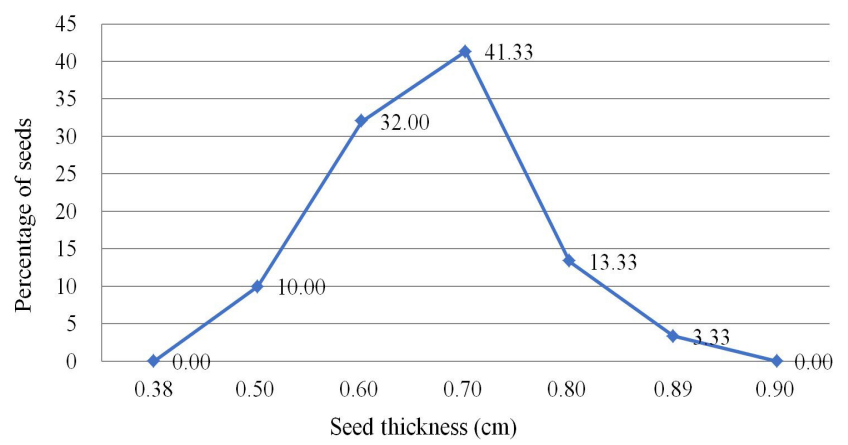

Fig. 3. A curve characterizing variability in thickness of sword bean seeds 
564

Table 3. Main development stages of sword bean plants produced in Poland in 2015 and 2016

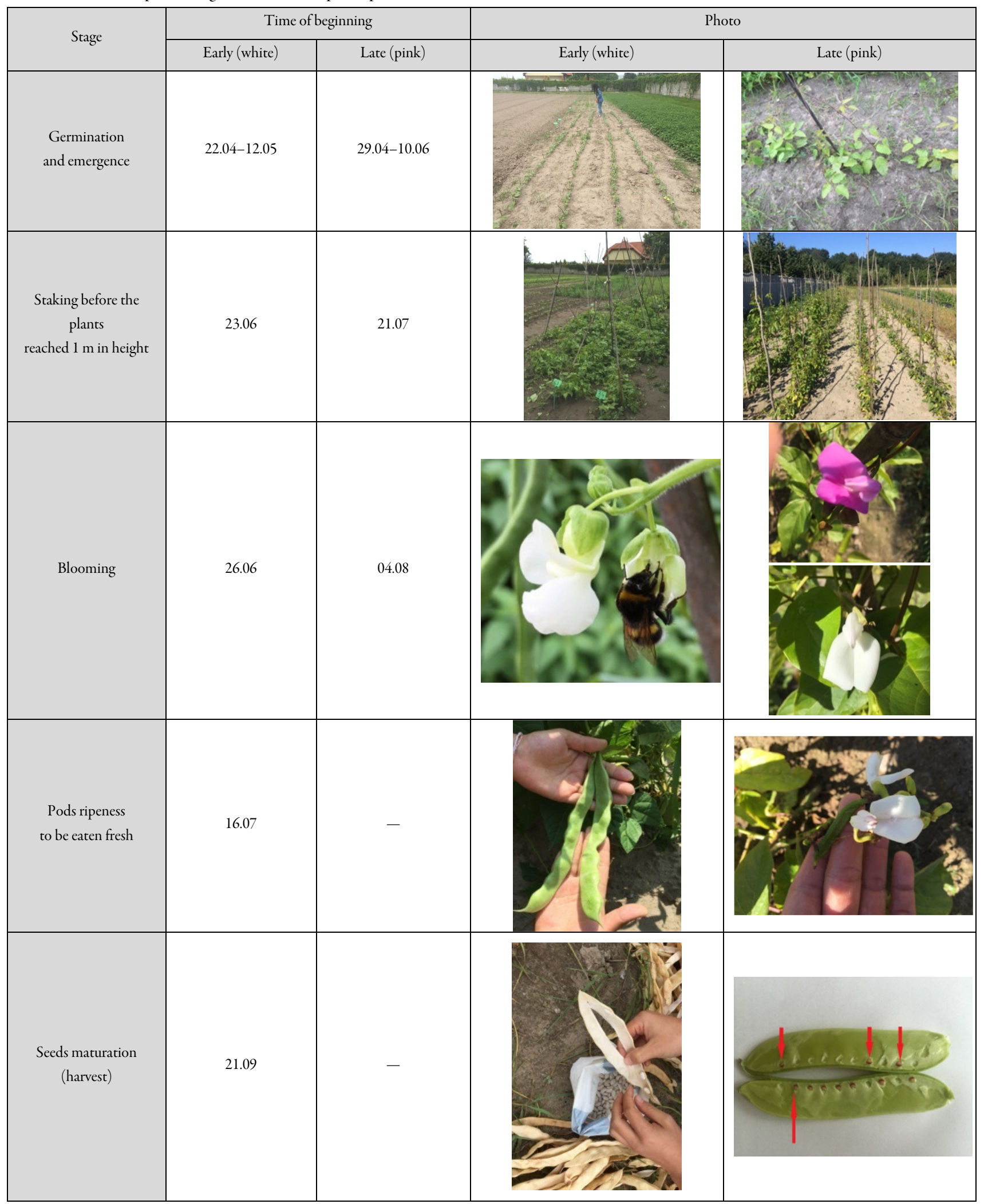

Table 4. Comparison of mean values and standard deviation (SD) values for measured seeds characters: length, width, thickness for three replicates of 50 seeds each

\begin{tabular}{|c|c|c|c|c|c|c|}
\hline \multirow{2}{*}{ Character } & \multicolumn{2}{|c|}{ Replicate 1} & \multicolumn{2}{|c|}{ Replicate 2} & \multicolumn{2}{|c|}{ Replicate 3} \\
\hline & Mean & SD & Mean & SD & Mean & SD \\
\hline Length $(\mathrm{cm})$ & 1.47 & 0.101 & 1.44 & 0.097 & 1.48 & 0.095 \\
\hline Width (cm) & 0.82 & 0.059 & 0.84 & 0.065 & 0.89 & 0.058 \\
\hline Thickness $(\mathrm{cm})$ & 0.56 & 0.072 & 0.63 & 0.065 & 0.69 & 0.083 \\
\hline
\end{tabular}


Weight of 1000 seeds

The produced seeds had 1000 seeds weight of $381.69 \mathrm{~g}$.

\section{Seed yield}

The recorded average number of seeds per pod was 7.3. The total weight of the harvested dry sword bean seeds was $2.48 \mathrm{~kg}$ per $12 \mathrm{~m}^{2}$. After re-calculation, it gave a total yield of $2,067.00 \mathrm{~kg}$ per hectare or $138.00 \mathrm{~kg} \mathrm{mu}^{-1}(1 \mathrm{ha}=15 \mathrm{mu})$. The total seed yield of the sword bean received in the experiment was around 6,500 individual seeds.

The seeds were healthy, white and with no symptoms of the diseases or pests harm. However, later on, in storage, about $20 \%$ of them were lost because of the bean weevil's damage.

\section{Germination test}

The results of the germination tests in sand of the harvested early cultivar seeds of sword bean (Table 5) showed that there was no significant difference between the 2 different temperatures used in both germination tests, neither at first nor at final counts. The same results were received for deformed seedlings, diseased seedlings as well as dead and fresh seeds. Although the germination capacity of the sword bean seeds at $15^{\circ} \mathrm{C}$ and $25^{\circ} \mathrm{C}$ showed no significant difference, the seedlings at $25^{\circ} \mathrm{C}$ were much longer than the ones received at $15^{\circ} \mathrm{C}$ (Photo 1 ).
Vigour test

Result of the vigour test on the blotter of the harvested seeds of sword bean at 2 different temperatures (Table 6) showed that both of $\mathrm{T}_{1}, \mathrm{~T}_{10}, \mathrm{~T}_{25}, \mathrm{~T}_{50}, \mathrm{~T}_{75}, \mathrm{~T}_{90}, \mathrm{U}_{75-25}, \mathrm{U}_{90-10}$ and mean germination time (MGT) at $25^{\circ} \mathrm{C}$ decreased than those at $15^{\circ} \mathrm{C}$. Their vigour measured by MGT was shorter at $25^{\circ} \mathrm{C}$ than at $15^{\circ} \mathrm{C}$.

\section{Water absorption capacity test}

When analyzing changes in seed weights during imbibition, two imbibition curves of sword bean seeds put into water were set (Fig. 4). In both of them, for the first 3 hours no differences were recorded. Then, for the 1 hour point the seeds produced in Poland absorbed water faster than the Chinese ones. However, 1 hour later, the difference between them disappeared. As a result, the curves, although different for the 1 hour point, were basically the same.

\section{Chemical contents of the seeds}

The chemical analysis of the early cultivar seeds of sword bean produced in Poland showed $80.81 \%$ of dry matter and $24.45 \%$ of total proteins contents (Table 7 ). The carried out chemical analysis of the late cultivar seeds of sword bean used for the experiment showed $87.80 \%$ of dry matter and $25.07 \%$ of total proteins contents.

Table 5. Results of the germination tests in the sand of the harvested seeds of early cultivar of sword bean at 2 different temperatures

\begin{tabular}{cccccc}
\hline Temp. & $\begin{array}{c}\text { Germination } \\
\text { first count }(\%)\end{array}$ & $\begin{array}{c}\text { Germination } \\
\text { final count }(\%)\end{array}$ & $\begin{array}{c}\text { Deformed } \\
\text { seedlings }(\%)\end{array}$ & $\begin{array}{c}\text { Diseased } \\
\text { seedlings }(\%)\end{array}$ & $\begin{array}{c}\text { Dead } \\
\text { seeds }(\%)\end{array}$ \\
\hline $15^{\circ} \mathrm{C}$ & $0.0 \mathrm{a}^{*}$ & $94.0 \mathrm{a}$ & $3.5 \mathrm{a}$ & $2.0 \mathrm{a}$ & $0.0 \mathrm{a}$ \\
$25^{\circ} \mathrm{C}$ & $0.0 \mathrm{a}$ & $94.5 \mathrm{a}$ & $4.0 \mathrm{a}$ & $0.5 \mathrm{a}$ & $0.5 \mathrm{a}$ \\
\hline${ }^{*}$ Means followed by the same letters are not significantly different according to the Duncan's test for $\alpha=0.05$ & $0.5 \mathrm{a}$ \\
\hline
\end{tabular}

${ }^{*}$ Means followed by the same letters are not significantly different according to the Duncan's test for $\alpha=0.05$

Table 6. Result of the vigour test based on MGT on the blotter of the harvested seeds of sword bean at 2 different temperatures

\begin{tabular}{ccccccccccc}
\hline Temp. & $\mathrm{T}_{1}{ }^{*}$ & $\mathrm{~T}_{10}$ & $\mathrm{~T}_{25}$ & $\mathrm{~T}_{50}$ & $\mathrm{~T}_{75}$ & $\mathrm{~T}_{90}$ & $\mathrm{U}_{75-25}$ & $\mathrm{U}_{90-10}$ \\
\hline $15^{\circ} \mathrm{C}$ & $1.46 \mathrm{~b}^{* *}$ & $1.93 \mathrm{~b}$ & $2.22 \mathrm{~b}$ & $2.55 \mathrm{~b}$ & $2.88 \mathrm{~b}$ & $3.18 \mathrm{~b}$ & $0.66 \mathrm{~b}$ & $1.25 \mathrm{~b}$ & $2.55 \mathrm{~b}$ \\
$25^{\circ} \mathrm{C}$ & $0.90 \mathrm{a}$ & $0.98 \mathrm{a}$ & $1.03 \mathrm{a}$ & $1.11 \mathrm{a}$ & $1.22 \mathrm{a}$ & $1.42 \mathrm{a}$ & $0.19 \mathrm{a}$ & $0.45 \mathrm{a}$ & $1.18 \mathrm{a}$
\end{tabular}

${ }^{*} \mathrm{~T}_{1}$ - time to $1 \%$ of maximum germination; $\mathrm{T}_{10}$ - time to $10 \%$ of maximum germination; $\mathrm{T}_{25}$ - time to $25 \%$ of maximum germination; $\mathrm{T}_{50}$ - time to $50 \%$ of maximum germination; $\mathrm{T}_{75}$ - time to $75 \%$ of maximum germination; $\mathrm{T}_{90}$ - time to $90 \%$ of maximum germination; $\mathrm{U}_{75-25}$ - time between $25 \%$ and $75 \%$ of maximum germination; U90-10- time between $10 \%$ and $90 \%$ of maximum germination; MGT- mean germination time

${ }^{* *}$ Means followed by the same letters are not significantly different according to the Duncan's test for $\alpha=0.05$
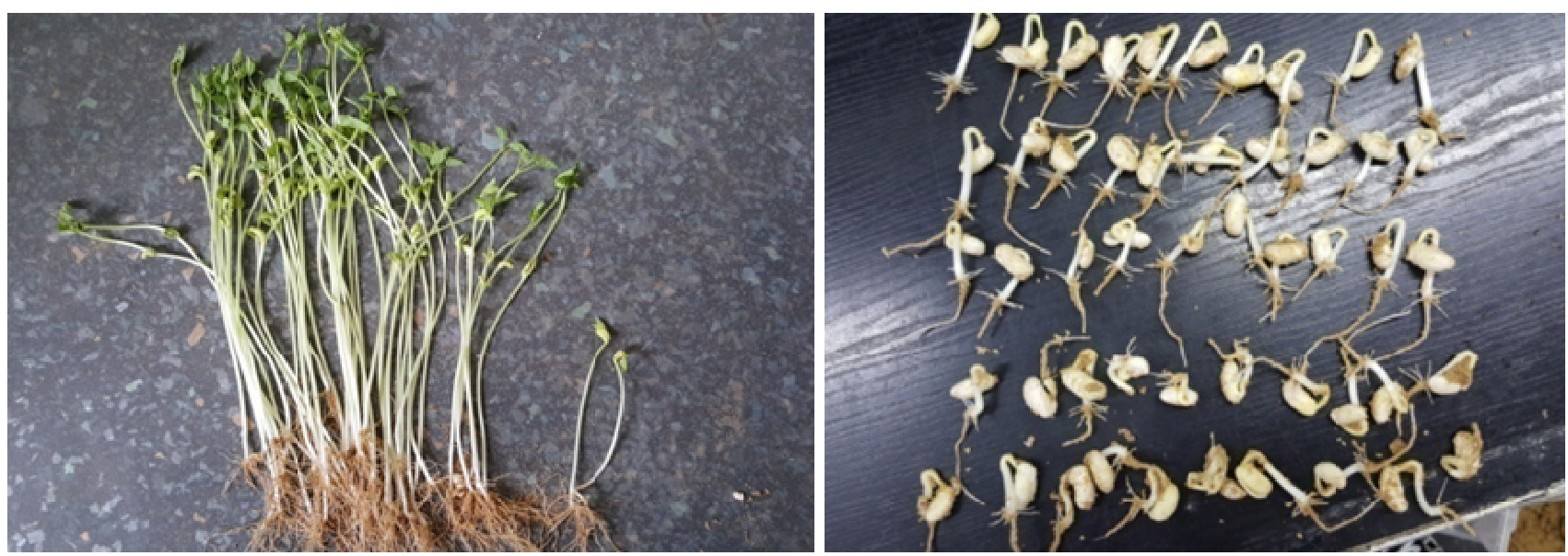

Photo 1. The final count of sword bean seedling in the germination test in the sand. Left: germination test at $25^{\circ} \mathrm{C}$. Right: germination test at $15^{\circ} \mathrm{C}$. Clearly seen difference in seedlings' length. The picture was taken in the W. Legutko Plant Breeding and Seed Production Company on December 11th, 2015 
Table 7. Results of chemical analysis of the two sword bean cultivars seeds, the early cultivar seeds were produced in Poland, the late ones were bought in China

\begin{tabular}{ccccc}
\hline \multirow{2}{*}{ Type of cultivar } & \multicolumn{2}{c}{ Dry matter $(\%$ d.w.) } & \multicolumn{2}{c}{ Total proteins (\% d.w.) } \\
\cline { 2 - 5 } & Average & $\begin{array}{l}\text { Standard } \\
\text { deviation }\end{array}$ & Average \\
deviation
\end{tabular}

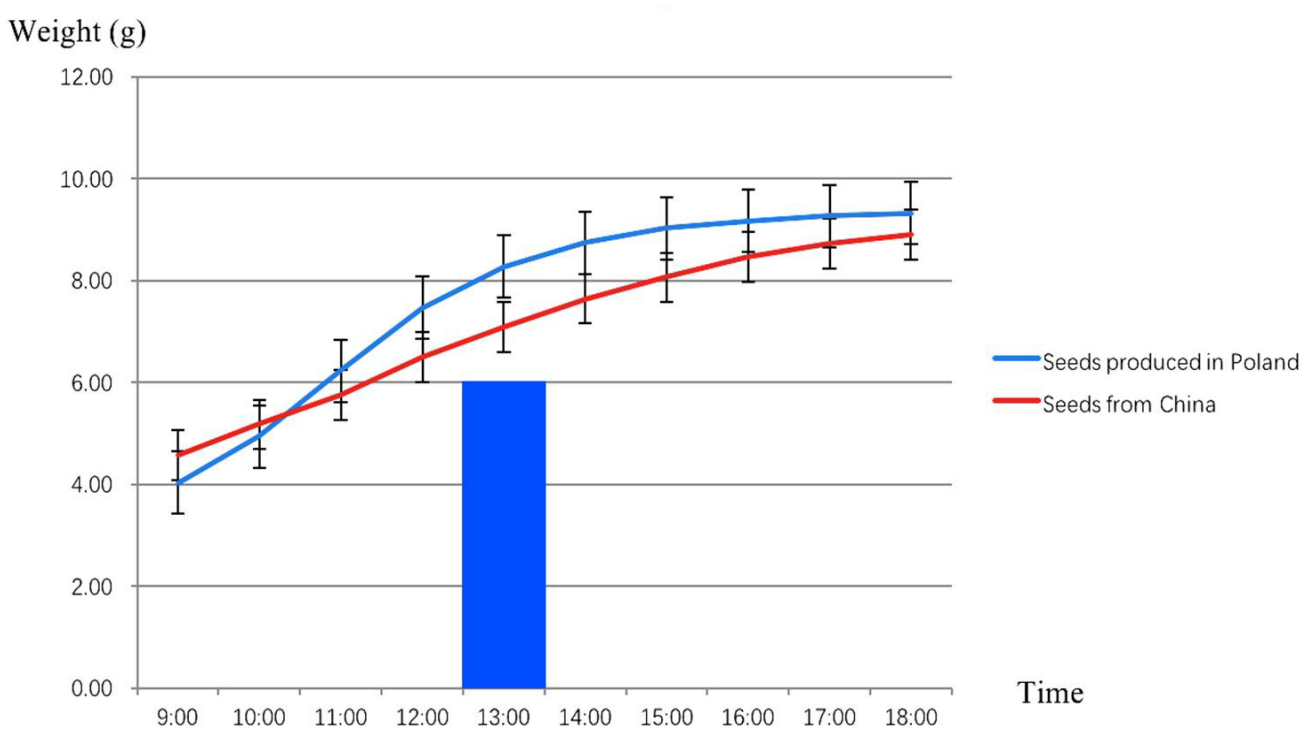

Fig. 4. Comparison of the first part of the imbibition curves of sword bean seeds from China and produced in the experiment in Poland (blue colour bar is for significant difference)

\section{Discussion}

In the carried-out experiment, both sword bean cultivars emergence rates were over $60 \%$. The breeder from the Chinese seed company provided on the seed bag information that the germination capacity (in the laboratory) of the seeds used in the experiment was over $85 \%$. However, in the field emergence rates were much lower than that. One of the reasons to explain it is the fact that the species is mostly cultivated in southern and southwestern China. The climatic conditions in Poland were much worse than there. After analyzing weather data from Marcelin, in Poland, one can learn that it was much colder in Poland than in China. The weather has been a crucial factor for sword bean production. This fact has been confirmed in the literature (Chen et al., 2001; Zhang and Yang, 2007).

The grown in Poland sword bean plants and seeds were susceptible to aphids and bean weevils. Two sprays of chemical eliminated aphids but did not eliminate bean weevils causing later on, in storage, as high as $20 \%$ damage of seeds. This observation was confirmed in the literature. Both aphids and bean weevils have been the main pests to be controlled in sword bean production (Ma et al., 2009).

The sword bean plants produced in Poland showed 5 main development stages. The growth cycle of the sword bean in China, from emergence stage to the seeds full maturation is 85 days, from emergence stage to the pods ready for eating is 45 days, and from blooming to pods ripeness is 20 days (Ma et al., 2009). In our experiment in Poland, these stages lasted much longer, i.e. 135 days, 75 days and 30 days, respectively. These results showed clearly that the whole growth cycle of sword bean produced in Poland was much longer than in China. These differences may be explained by the climatic conditions in the experiment. In Poland, the average temperature for plant emergence was $13.3^{\circ} \mathrm{C}$, and for pods growing $-19.4^{\circ} \mathrm{C}$. The optimal temperature for sword bean plant emergence is 18 $20{ }^{\circ} \mathrm{C}$ and $18-25^{\circ} \mathrm{C}$ for pods growing (Ma et al., 2009). The carried-out experiment proved that weather conditions (air day temperatures and sum of monthly precipitations) was a crucial factor in the crop's field production in Poland. The optimal conditions could be shortly described as hot and wet. During the vegetation, the air temperature in Poland was below the optimal one, and it led to a longer growth period of the plants produced there. In the most important (blooming and pods setting) two months: July and August, although the temperatures were typical for Polish vegetation period, still these values were lower than the optimal ones (Shao, 2015).

The selected late cultivar of sword bean was found out to be too late for the climatic conditions in Western Poland. As a result, it produced no ripen seeds, they were soft and immature ones of the size of wheat grain. Moreover, due to the chilling and frosts, they could not be kept longer in the field.

In our experiments, the most stable seed character of sword bean was width and the least stable - length. This is in agreement with the information provided by $\mathrm{Bi}$ and Dai (1999). Out of the measured plant and seeds characters, number of seeds per pod, on average, was 7.3 seeds per pod. This value was smaller than in China, where usually it sets from 8 to 12 seeds per pod (Chen, 2001; Ma et al., 2009). 
A total seed yield recorded for sword bean in the field experiment was 2,067.00 kg per hectare. The seed yield in China is $2,250.00 \mathrm{~kg}-3,750.00 \mathrm{~kg}$ per hectare in common and it is higher than the one in Poland. This may come from 2 reasons: 1 . The air temperature during the growth period of sword bean in Poland was lower than in China where the sword bean seeds are produced. 2 . The sowing method in Poland is different from the one in China. In Poland, the sowing method was 200 seeds in one 8-meter long row, in which seeds were sown individually. In China, 2 or 3 seeds in one hole are sown and the distance between two holes is $30-50 \mathrm{~cm}$. In Poland, there was smaller distance between seeds than in China. As a result, it led to easier infection of pests and diseases. The cultivation method of sword bean in China (Lu and Liu, 1987; Shao, 2015) is better than the one used in Poland.

The harvested seeds germinated in $94.0 \%$ and $94.5 \%$ in sand at $15^{\circ} \mathrm{C}$ and $25^{\circ} \mathrm{C}$, respectively. Their vigour measured by MGT was shorter for $25^{\circ} \mathrm{C}$ than for $15^{\circ} \mathrm{C}$. Better seeds germination at $25^{\circ} \mathrm{C}$ than at $15^{\circ} \mathrm{C}$ is in agreement with information from many other papers and books, in which temperature had been shown to be a crucial factor affecting seed germination (Copeland and McDonald, 1995; McDonald and Copeland, 1997; Ponnuswami et al., 2012). Also, shorter MGT at $25^{\circ} \mathrm{C}$ than at $15^{\circ} \mathrm{C}$ is in agreement with findings of other authors (Copeland and McDonald, 1995; Bi and Dai, 1999).

The imbibition curves for the early cultivar seeds of sword bean produced in Poland and in China, although significantly different for the 1 hour point, were basically the same. Such imbibition curves of beans, if different, could be related to specific responses of bean seeds to germination factors (Holubowicz et al., 1988). The same was observed for bean seeds' drying dynamics and their relation to seed viability (Ratajczak and Holubowicz, 2008). In previous paper, sword bean seeds finished $85.6 \%$ water absorption, and the seeds continued absorbing water in the following 5 days and then reached the stable situation to germinate. During these days, enough absorbed water supplied the seeds of high both vigour and tolerance to the adversity stress. Our results showed clearly that in the cultivation of the sword bean by directly sowing, the irrigation in the first 6 days must be sufficient, what was also confirmed by Zhang and Yang (2007).

The chemical analysis of the harvested early cultivar seeds showed $80.81 \%$ of dry matter and $24.45 \%$ of total proteins contents. For the late cultivar seeds used for the experiment, they were $87.80 \%$ and $25.07 \%$, respectively. For the harvested seeds in Poland, these values were a little lower than the values one could find in Chinese literature, in which, the dry matter and total proteins contents were $84 \%$ and 25-27\%, respectively (Chen et al., 2001; Ma et al., 2009). Still, taking under consideration the climatic conditions during the vegetation period in Poland, the received results were good and almost the same as for the seeds produced in China. The standard total proteins content of the common beans is $20-40 \%$ (Chen, 2001). The chemical parameters of sword bean seeds produced in Poland fit it and they were valuable for both eating and processing.

\section{Conclusions}

In the climatic conditions of Western Poland, it was possible to produce germinating seeds of sword bean, but only for the early cultivar, not for the late one. The yield and quality of them were high. The latter included seed germination, vigour, water absorption and size. The chemical analysis of the harvested early cultivar seeds showed $80.81 \%$ of dry matter and $24.45 \%$ of total proteins contents.

\section{References}

Anonymous (2012). International Rules for Seed Testing ISTA Bassersdorf Switzerland. Chapter 5: the germination test, ISTA.

Bi XH, Dai XW (1999). Seed Science (in Chinese). China Agriculture Press 86.

Black M, Bewley JD, Halmer P (2006). The Encyclopedia of Seeds. Science, Technology and Uses. CAB International, London, UK 696.

Chen $\mathrm{H}$ et al. (2001). Atlas of the Traditional Vegetables in China (in Chinese). Zhejiang Science and Technology Publishing House, ZhejiangProvince, China 40:147-159.

Copeland LO, McDonald MB (1995). Principles of Seed Science and Technology. Chapman and Hall, Minneapolis.

Drzazga B (1999). Technical analysis in food industry (in Polish). WSiP Warszawa.

Du DL, Li Y, Fan HY (2009). High yield techniques of sword bean organic cultivation (in Chinese). Modern Agricultural Sciences and Technology 24:132.

Duranti M (2006). Grain legume proteins and nutraceutical properties. Fitoterapia 77:67-82.

Ekanayake S, Jansz ER, Baboo M (2000). Literature review of an underutilized legume: Canavalia gladiata L. Plant Foods for Human Nutrition 55:305-321.

Hotubowicz R, Taylor AG, Goffinet MC, Dickson MH (1988). Nature of semi-hand seed characteristic in snap beans. Journal of American Society Horticultural Science 113:248-252.

Huang YF (2008). The characteristics of French sword bean and high yield techniques of French sword bean cultivation (in Chinese). China Fruit and Vegetable 1:18.

Kryłowska-Kulas M (1993). Food products quality evaluation (in Polish). PWE, Warszawa.

Li N, Li X, Feng ZG, Masayuki Y (2007). Chemical constituents from Canavalia gladiate (in Chinese). Journal of Shenyang Pharmaceutical University 24(11):676-678.

Liu SX (1994).The adaptability studies of swordJack bean in the middle and south area in Hebei Province (in Chinese). Journal of Hebei Agricultural University 17:156-159.

Lu JH, Liu Y (1987). Cultivation techniques of sword bean (in Chinese). Chinese Traditional Medicine Notification 12(5):20.

Luo SF, Hu LH, Chen YY, Li PX (2015). The effects of modified atmosphere packaging on the quality of sword bean storage and antioxidant enzyme activities (in Chinese). Food Science 17:1-8. 
568

MaDX et al. (2009). Sword bean. In: Cultivation of Chinese Vegetables (in Chinese) SecondEd, China Agriculture Press, Beijing China 787-789.

McDonald MB, Copeland LO (1997). Seed production: principles and practices. Chapman and Hall, Minneapolis.

Moteetee AN (2016). Canavalia (Phaseoleae, Fabaceae) species in South Africa: naturalised and indigenous. South African Journal of Botany 103(3):6-16.

Ponnuswami V, Geetharani P, Swaminathan V (2012). Factors affecting vegetable seed production. In: "Seed Technology of Horticultural Crops”. Narenda Publishing House, Delhi,73-80.

Ratajczak K, Hołubowicz R (2008). Effect of common bean (Phasedus vulgaris $\mathrm{L}$.) seed quality on their drying dynamics. Folia Horticulturae 20(2):85-92.
Shao SY (2015). Organic production of sword bean in the semi-drought conditions (in Chinese). Agricultural Development and Equipment $1: 142$.

Yang XH, MaSB (2010). The control techniques of sword bean root rot (in Chinese). Vegetables 4:19.

Yang D, Lei YG, Liu M, Zhang SX (2014). Therapeutic effect of 5\% amino oligosaccharide water on the chilling injury of sword bean (in Chinese). Modern Agricultural Technology 7:145-149.

Zhang HY, Yang SS (2007). Characteristics of sword bean seeds germination (in Chinese). Crops 6:38-39.

Zhu JB, Wang HX (2002). The comprehensive development and utilization of Canavalia ensiformis (in Chinese). Chinese Wild Plants Research 3:17-19. 